\title{
BIẾN ĐỔI TRONG HOẠT ĐỘNG KINH TẾ CỦA NGƯÒ̀I CƠ-HO Ở TỈNH LÂM ĐỒNG TÙ ĐỔI MỚI ĐẾN NAY
}

\author{
Lê Minh Chiến ${ }^{a^{*}}$, Mai Minh Nhật ${ }^{\mathrm{b}}$
}

${ }^{a}$ Khoa Công tác Xã họi, Trường Đại học Đà Lạt, Lâm Đồng, Việt Nam

${ }^{b}$ Khoa Lịch sủ, Truò̀ng Đại học Đà Lạt, Lâm Đồng, Việt Nam

Lịch sử bài báo

Nhận ngày 26 tháng 10 năm 2017

Chỉnh sửa ngày 28 tháng 11 năm 2017 | Chấp nhận đăng ngày 29 tháng 11 năm 2017

\section{Tóm tắt}

Bài viết này nghiên cứu nhũng biến đổi trong hoạt động kinh tế của người Cơ-ho ở tỉnh Lâm Đồng dưới sự tác động của chính sách Đổi mới của Đảng và Nhà nước, cũng nhu của quá trình công nghiệp hóa, hiện đại hóa và hội nhập quốc tế và nhũng chuyển biến kinh tế - xã họi tại địa phưong tù năm 1986 đến nay. Bài viết cũng phân tích nhũng thách thức đang đặt ra đối với sự phát triển kinh tế bền vũng của người Co-ho trong giai đoạn hiện nay.

Từ khóa: Biến đổi kinh tế; Hoạt động kinh tế; Người Cơ-ho; Tỉnh Lâm Đồng.

\section{GIỚI THIỆU}

Người Cơ-ho (K'ho, Kơ Ho, Cơ Ho) là một trong 12 tộc người tại chỗ ở Tây Nguyên, cư trú tập trung chủ yếu trên địa bàn tỉnh Lâm Đồng (chiếm hơn $87 \%$ ), số còn lại cư trú rải rác ở các huyện miền núi của các tỉnh Khánh Hòa, Ninh Thuận, Bình Thuận. Tính đến ngày 01/4/2009, người Cơ-ho ở Lâm Đồng có 145.665 người, cư trú trải rộng trên địa bàn các huyện Lạc Dương, Đức Trọng, Đơn Dương, Lâm Hà, Đam Rông, Di Linh, Bảo Lâm, thành phố Bảo Lộc và thành phố Đà Lạt. Với số dân khá đông và bề dày văn hóa của mình, người Cơ-ho là tộc người tại chỗ đóng vai trò quan trọng tại khu vực Nam Tây Nguyên.

Tương tự các cư dân khác ở khu vực Trường Sơn - Tây Nguyên, trong truyền thống, nền kinh tế của người Cơ-ho ở Lâm Đồng mang nặng tính tự cung, tự cấp, khép kín và phụ thuộc chặt chẽ vào tự nhiên. Từ năm 1975, đặc biệt là từ năm 1986 đến nay, do nhiều nguyên nhân khác nhau, nhất là hiệu quả của các chính sách, chương trình, dự án đầu tư liên quan đến phát triển kinh tế vùng dân tộc thiểu số của Nhà nước, hoạt động

\footnotetext{
* Tác giả liên hệ: Email: chienlm@dlu.edu.vn
} 
kinh tế của người Cơ-ho đã có sự thay đổi sâu sắc trên nhiều phương diện, theo hướng tham gia mạnh mẽ vào mô hình sản xuất nông nghiệp hàng hóa gắn với thị trường. Sự phát triển trong hoạt động kinh tế đã tạo những tiền đề quan trọng, dẫn đến những biến đổi trên các phương diện xã hội - văn hóa của tộc người này. Bên cạnh mảng màu tích cực nổi trội và chiếm ưu thế, sự biến đổi kinh tế của tộc người này hiện cũng đang đặt ra một số vấn đề mang tính chất nổi cộm, bức xúc cần giải quyết. Chính vì vậy, nghiên cứu sự biến đổi kinh tế của người Cơ-ho trong bối cảnh đương đại và nhận diện những thách thức đang đặt ra là việc làm có ý nghĩa khoa học và thực tiễn.

Cho đến nay, chưa có chuyên khảo về biến đổi kinh tế của người Cơ-ho ở Lâm Đồng từ năm 1986 đến nay. Tuy vậy, vấn đề này đã ít nhiều được đề cập trong các công trình nghiên cứu miêu thuật về người Cơ-ho: Nguoơi Co ho ở Việt Nam (Bùi, 2003), Người Ko Ho ở Lâm Đồng nghiên cúu nhân học về dân tộc và văn hóa (Phan, 2005), hoặc được đề cập đến trong một số bài viết: "Một số biến đổi kinh tế - xã hội của người Cơ-ho ở huyện Di Linh, tỉnh Lâm Đồng trong thời kỳ đổi mới” của Bùi (2016) và "Biến đổi kinh tế - xã hội của các dân tộc thuộc nhóm ngôn ngữ Môn - Khmer từ Đổi mới đến nay và những vấn đề nghiên cứu đặt ra” của Vũ (2016). Ngoài ra, một số công trình nghiên cứu về các vấn đề chuyển đổi sinh kế, tín dụng, nông dân - nông thôn - nông nghiệp... ở Tây Nguyên trong phát triển bền vững của Hoàng, Ngô, Hoàng, Vũ, và Nguyễn (2017); Bùi (2016); và Lê (2016),... cũng đã chọn một số cộng đồng Cơ-ho ở Lâm Đồng làm điểm khảo sát. Những số liệu và kết quả khảo sát tại các cộng đồng người Cơ-ho không được trình bày thành hệ thống riêng trong các công trình nghiên cứu mang tính chất khái quát cho cả vùng Tây Nguyên nhưng cũng đã cung cấp nguồn tư liệu bổ ích cho chúng tôi so sánh, đối chiếu, làm rõ thêm chủ đề nghiên cứu của bài viết.

Tư liệu sử dụng trong bài viết này chủ yếu là tư liệu điền dã của nhóm tác giả tại một số vùng người Cơ-ho ở Lâm Đồng. Cùng với những tư liệu định tính thu thập bằng các phương pháp phỏng vấn sâu, quan sát tham dự, chúng tôi cũng sử dụng những tư liệu định lượng thu thập được bằng phương pháp điều tra xã hội học với bảng hỏi cấu trúc. Cuộc khảo sát được tiến hành tại 3 xã có đông người Cơ-ho cư trú ở 3 huyện: N'thôl Hạ (huyện Đức Trọng), Gung Ré (huyện Di Linh) và Đạ Long (huyện Đam Rông). Tại mỗi xã chúng tôi khảo sát 100 hộ gia đình theo phương pháp chọn mẫu ngẫu nhiên dựa trên 
danh sách chủ hộ. Người trả lời phiếu khảo sát chủ yếu là chủ hộ - người nắm vững tình hình kinh tế hộ gia đình. Bảng câu hỏi được thiết kế cho một cuộc phỏng vấn trực tiếp giữa điều tra viên và người được hỏi trong một không gian đảm bảo tính riêng biệt và độc lập trong các câu trả lời của người được hỏi.

\section{KINH TẾ TRUYỀN THỐNG CỦA NGƯỜI CO'-HO}

Trong truyền thống, nền kinh tế của người Cơ-ho khá đa dạng, trong đó trồng trọt đóng vai trò chủ yếu. Tùy thuộc vào đặc điểm tự nhiên địa bàn cư trú, mỗi nhóm địa phương lựa chọn một loại hình canh tác chính.

Người Cơ-ho Srê cư trú ở các thung lũng ven sông, suối, có những bãi bồi phù sa, có nước tưới thuận lợi nên làm ruộng nước (lơh srê) là hoạt động kinh tế truyền thống quan trọng, được người dân ưu thích nhất (tên gọi Srê của nhóm địa phương này có nghĩa là ruộng nước). Tương tự như các cư dân làm ruộng khác ở Tây Nguyên như người Giarai ở vùng thung lũng Cheo reo (tỉnh Gia Lai), người Êđê Bih vùng buôn Trấp ven sông Sêrêpôk, người Mnông Rlâm ven hồ Lăk (tỉnh Đăk Lăk) hoặc người Churu ở vùng Đức Trọng, Đơn Dương (Lâm Đồng),... kỹ thuật canh tác ruộng nước của người Cơ-ho Srê có hai loại: Ruộng trâu quần và ruộng dùng cày, bừa. Bên cạnh canh tác lúa nước là chủ đạo, nương rẫy cũng là loại hình canh tác quan trọng trong cơ cấu kinh tế của người Cơ-ho Srê.

Khác với người Cơ-ho Srê, người Cơ-ho Chil trước kia cư trú ở vùng núi cao phía Đông Bắc tỉnh Lâm Đồng nên canh tác lúa nước hoàn toàn vắng mặt trong cơ cấu kinh tế truyền thống của họ, thay vào đó, làm nương rẫy ( $s a$ bri - ăn rừng) đóng vai trò chủ đạo. Người Chil tùy từng khu vực cư trú có thể chọn lúa rẫy (koi mir) hoặc bắp (mpô) làm cây trồng chính. Kỹ thuật và quy trình canh tác nương rẫy của người Chil không có nhiều khác biệt với các cư dân bản địa Trường Sơn - Tây Nguyên. Đó là loại hình canh tác du canh luân khoảnh, với các công đoạn chọn rẫy - phát rẫy - phơi khô - đốt rẫy - gieo tỉa chăm sóc - thu hoạch gắn với hệ thống nông lịch chặt chẽ trải dài hơn 10 tháng/năm. Cùng với đó là những những kinh nghiệm phong phú tích lũy được về chọn đất rẫy, chọn giống, đoán biết các hiện tượng thời tiết... Công cụ chủ yếu được sử dụng trong quá trình canh tác là rìu, rựa, cuốc, đặc biệt là chà gạc (wieh - một loại công cụ chặt phổ biến, hiệu quả 
và được các cư dân ở Nam Tây Nguyên rất ưu chuộng). Bên cạnh cây trồng chính, họ còn trồng xen nhiều loại cây rau màu (đậu, bí, bầu, mướp, khoai ớt, bông vải, dưa...) nhằm tự đáp ứng nhu cầu lương thực, thực phẩm của gia đình mình. Canh tác nương rẫy luân canh, đa canh là loại hình canh tác thích ứng tốt với điều kiện tự nhiên vùng rừng núi, không thuận lợi về nước tưới. Ngoài ra, đây là loại hình canh tác thân thiện với tự nhiên, vừa bảo vệ tốt các nguồn lợi tự nhiên, vừa đáp ứng được nhu cầu con người trong bối cảnh đất rộng, người thưa trước kia. Kinh nghiệm được tổng kết ở nhiều nơi trên thế giới cho thấy nếu mật độ dân số không quá 21 người $/ \mathrm{km}^{2}$ thì việc làm nương đốt không hề ảnh hưởng đến môi trường sinh thái tự nhiên và rừng luôn kịp tái sinh theo chu kỳ canh tác quay vòng (Mai, 2012, tr.16).

Người Cơ-ho Lạch cư trú tập trung ở vùng cao nguyên Lang Biang (thuộc Đà Lạt và Lạc Dương ngày nay) với địa hình đồi núi thoai thoải, xen với các con suối lớn nhỏ nên với họ, canh tác ruộng nước và nương rẫy đều có vị trí quan trọng trong sinh kế. Trong đó, canh tác ruộng nước được người Lạch có xu hướng ưu chuộng hơn. Kỹ thuật canh tác ruộng nước và nương rẫy của người Cơ-ho Lạch không khác nhiều so với người Cơ-ho Srê, Cơ-ho Chil.

Cùng với trồng trọt, các gia đình người Cơ-ho có chăn nuôi các loại gia súc, gia cầm: Gà, lợn, trâu,.... Ở cộng đồng người Cơ-ho Lạch, ngựa cũng là vật nuôi khá được ưa thích, để thồ hàng và để làm phương tiện di chuyển. Người Cơ-ho chủ yếu nuôi thả rông, chưa nuôi nhốt. Heo, gà thả rông trong làng, trâu thả rông trong rừng, định kỳ lên thăm và khi có nhu cầu thì mới bắt về. Trước kia, các vật nuôi chủ yếu phục vụ cho nhu cầu tế lễ, nghi thức phạt vạ theo luật tục, trao đổi quà tặng trong hôn nhân và phục vụ cho hoạt động trao đổi.

Sống ở vùng rừng núi, là "những người của rừng”, nên các hoạt động kinh tế chiếm đoạt như săn bắt, đánh bắt cá, hái lượm sản vật từ rừng đóng một vai trò quan trọng trong đời sống người Cơ-ho. Hoạt động này vừa mang tính bản năng của "tiềm thức núi rừng”, vừa là hoạt động giải trí, đồng thời góp phần quan trọng bổ sung nguồn thực phẩm cho bữa ăn hằng ngày và cung cấp các sản vật rừng để trao đổi những thứ không tự làm ra được. 
Các ngành nghề thủ công (đan lát, dệt vải, rèn, làm gốm) cũng được người Cơ-ho thực hiện trong truyền thống. Trong đó, đan lát là hoạt động phổ biến nhất, với các sản phẩm gùi, chiếu, dụng cụ đánh bắt cá... chủ yếu phục vụ cho nhu cầu của mỗi gia đình. Trong hầu hết các làng, đều có 1 đến 2 người thạo nghề rèn, đáp ứng nhu cầu rèn, sửa công cụ lao động. Ở cộng đồng người Cơ-ho Srê, nghề dệt vải khá phổ biến. Riêng nhóm Cơ-ho Lạch không biết đến trồng bông, xe sợi, dệt vải. Với nhóm Cơ-ho Chil, chỉ có người Cơ-ho Chil gốc Bon Ja có nghề dệt. Sản phẩm dệt của người Cơ-ho bền, đẹp với các sản phẩm khố, áo, váy, tấm đắp. Trước kia, tại một số làng ven sông ở Đam Rông, Di Linh có nguồn đất sét mịn, một số gia đình người Cơ-ho biết làm đồ gốm, tạo ra một số sản phẩm gốm thô đơn giản, không men (nồi nhỏ, chén ăn cơm, vò đựng nước) với kỹ thuật đơn giản, không bàn xoay, nung lộ thiên.

Nền kinh tế của người Cơ-ho trong truyền thống mang nặng tính tự cung, tự cấp, khép kín, mỗi gia đình, mỗi bon cố gắng tự thỏa mãn mọi nhu cầu của mình. Tuy vậy, với nhiều loại sản phẩm không thể tự làm ra, họ buộc phải trao đổi với các cộng đồng khác: Sắt để rèn công cụ, cồng chiêng, nồi đồng, chóe và đặc biệt là trao đổi muối với người Chăm ở miền duyên hải phía Đông. Hoạt động trao đổi chủ yếu là vật đổi vật, không có vai trò của tiền, vàng mà nổi lên là trâu, chiêng, ché, các sản vật từ rừng.

Tóm lại, do điều kiện tự nhiên nơi cư trú, truyền thống văn hóa, dân số, phân bố dân cư và bối cảnh lịch sử - xã hội, nền kinh tế của người Cơ-ho truyền thống mang tính tự nhiên, tự cung tự cấp. Mặc dù còn bấp bênh, khó khăn nhưng với áp lực dân số không lớn, trong điều kiện tự nhiên ưu đãi (rừng núi rộng lớn và giàu có, đất đai màu mỡ), các hoạt động kinh tế này cũng đã đáp ứng được cơ bản nhu cầu lương thực, thực phẩm nuôi sống con người, đồng thời bảo tồn được nguồn tài nguyên rừng. Những hoạt động sinh kế đó ảnh hưởng lớn đến văn hóa - xã hội của người Cơ-ho: Chế độ chiếm hữu đất đai tập thể, hệ thống tri thức bản địa phong phú trong quản lý và sử dụng các nguồn tài nguyên thiên nhiên, tri thức về các hiện tượng thời tiết tự nhiên, nhịp sống và đời sống tín ngưỡng gắn theo chu kỳ canh tác nương rẫy,... Tất cả đã góp phần tạo nên một diện mạo văn hóa rừng vừa nằm trong tổng thể không gian văn hóa xã hội vùng Tây Nguyên, vừa mang những nét riêng của văn hóa tộc người Cơ-ho. 


\section{BIẾN ĐỔI TRONG HOẠT ĐỘNG KINH TẾ CỦA NGƯỜI CƠ-HO TỬ ĐỔI MỚI ĐẾN NAY}

Từ năm 1975, đặc biệt là từ năm 1986 - thời điểm đất nước tiến hành công cuộc Đổi mới đến nay, hoạt động kinh tế của người Cơ-ho ở Lâm Đồng đã có nhiều biến đổi so với truyền thống. Đó là kết quả tổng hòa của nhiều nguyên nhân chủ quan và khách quan: chính sách đất đai và các chương trình, dự án đầu tư phát triển của Nhà nước, kinh tế thị trường hàng hóa, sức ép tăng dân số, sự phát triển của thông tin liên lạc, giao lưu văn hóa tộc người, biến đổi đặc điểm không gian tự nhiên - xã hội... Trong đó, các chương trình, chính sách phát triển của Nhà nước đóng vai trò chi phối mạnh mẽ nhất. Do người Cơ-ho cư trú trải rộng gần khắp địa bàn tỉnh Lâm Đồng, ở những nơi có điều kiện tự nhiên, cơ sở hạ tầng, đặc điểm phát triển kinh tế - xã hội khác nhau nên tốc độ, mức độ và quy mô biến đổi kinh tế không đồng đều. Nhìn chung, đời sống kinh tế của những cộng đồng ở gần đô thị, trung tâm huyện lỵ, gần các trục lộ giao thông chính, có đất đai màu mỡ và điều kiện tự nhiên thuận lợi có sự thay đổi mạnh mẽ, rõ rệt và nhanh hơn những cộng đồng ở vùng sâu, vùng xa (Vũ, 2016, tr. 65).

Sự biến đổi kinh tế của người Cơ-ho ở Lâm Đồng thể hiện trên nhiều phương diện, nổi bật là sự du nhập mạnh mẽ của những phương thức sản xuất nông nghiệp mới khác hẳn phương thức sản xuất truyền thống cả về kỹ thuật canh tác, hệ cơ cấu cây con, hình thức khai thác, tiêu thụ sản phẩm. Bên cạnh đó, xuất hiện thêm một số hoạt động tương đối mới như dịch vụ, mua bán, làm thuê.

Về cơ cấu kinh tế, trong tổng số 300 hộ trong mẫu điều tra, có 287 hộ thuần nông (95.6\%), 8 hộ hỗn hợp nông nghiệp - dịch vụ (2.7\%), 5 hộ phi nông (1.7\%). Như vậy, nông nghiệp vẫn đóng vai trò chủ đạo trong cơ cấu kinh tế của người Cơ-ho. Nhưng khác với truyền thống, nền kinh tế này không còn mang tính chất tự cung, tự cấp khép kín mà chuyển đổi mạnh mẽ theo hướng thâm canh, sản xuất hàng hóa, thâm nhập sâu vào kinh tế thị trường với cà phê là cây trồng chủ lực.

Cây cà phê được người Pháp đưa vào Lâm Đồng khá sớm, chủ yếu được trồng trong các đồn điền sử dụng sức lao động của người dân tộc tại chỗ và người Kinh nhập cư. Từ đầu thập niên 1980, do giá cà phê tăng nhanh, thu hoạch từ cà phê có giá trị cao 
hơn nhiều so với các loại cây truyền thống, điều kiện đất đai thổ nhưỡng phù hợp và chủ trương khuyến khích chuyển đổi sang trồng cây công nghiệp của chính quyền nên phong trào trồng cà phê phát triển rộng khắp các hộ gia đình người Cơ-ho ở Lâm Đồng. Theo kết quả khảo sát, có $94.4 \%$ hộ trong mẫu điều tra có canh tác cà phê và đây cũng là nguồn thu chính của hầu hết các gia đình.

Tương tự nhiều nơi khác ở Tây Nguyên, khi chuyển từ canh tác nương rẫy với phương thức du canh luân khoảnh sang sử dụng lâu dài một khoảng đất, thâm canh cây cà phê, người Cơ-ho phải thay đổi toàn diện đặc điểm sản xuất của mình (Mai, 2012, tr 40-41). Về kỹ thuật sản xuất, từ xen canh và đa canh chuyển dần theo hướng đơn canh, từ quảng canh sang đầu tư thâm canh, từ chọc lỗ tra hạt không dùng phân bón sang cày xới, đào bồn để bón phân để tránh bị rửa trôi vào mùa mưa và giữ ẩm vào mùa khô. Công cụ sản xuất trong tất cả các khâu của quá trình sản xuất đều thay đổi: Chuyển từ các công cụ thô sơ (gậy chọc lỗ, chà gạc, rựa, rìu, gùi,...) sang công cụ cơ giới hiện đại (máy cày, máy phay đất, máy bơm nước, máy cắt cỏ, máy bóc vỏ cà phê.,..). Mục tiêu sản xuất chuyển từ tự cung tự cấp sang phục vụ sản xuất hàng hóa, với 100\% sản phẩm cà phê được bán ra thị trường để lấy tiền mua lại từ thị trường các nhu yếu phẩm, vật dụng phục vụ cho nhu cầu cuộc sống. Cách thức tiếp nhận kỹ thuật chuyển từ truyền miệng, học qua kinh nghiệp thực hành và tích lũy lâu đời được lưu truyền trong cộng đồng sang cách tiếp nhận qua quan sát cách làm của người ở nơi khác chuyển đến, qua sách báo, đài truyền thanh, truyền hình, từ các cán bộ khuyến nông qua các lớp tập huấn, tham quan thực tế.

Việc mở rộng diện tích canh tác và cơn sốt giá cà phê trong hai thập niên 1980, 1990 đã có ảnh hưởng lớn đến đời sống của người Cơ-ho ở nhiều địa phương, nhất là ở các địa bàn có nguồn đất bazan màu mỡ như Di Linh, Đức Trọng, Lâm Hà, Lạc Dương. Thu nhập cao từ cây cà phê đã giúp cho nhiều gia đình thoát nghèo, trở nên khá giả, một số gia đình người Cơ-ho trở thành những “triệu phú”, nhiều bon Cơ-ho được khởi sắc, trở nên trù phú. Điển hình như xã Tân Châu, huyện Di Linh - một địa phương có đông người Cơ-ho Srê cư trú đã trở thành xã triệu phú nhờ thu nhập từ cà phê và đã được nhà nước phong tặng danh hiệu Xã anh hùng lao động trong thời kỳ đổi mới (Bùi, 2016, tr. 49-50). Có thể nói, việc canh tác cà phê đã góp phần chuyển hướng nền kinh tế của người Cơ-ho ở Lâm Đồng từ tự cung, tự cấp truyền thống sang theo hướng sản xuất hàng hóa, hòa nhập 
sâu và gắn chặt với thị trường. Tuy vậy, việc canh tác cây cà phê - một loại cây trồng đòi hỏi đầu tư nhiều phân bón, nước tưới và công chăm sóc, giá cả sản phẩm lại phụ thuộc vào thị trường quốc tế có nhiều biến động cũng gây ra không ít khó khăn cho người Cơho, đặc biệt là những hộ ở vùng sâu, vùng xa, có ít đất đai và hạn chế về vốn và lao động.

Từ sau năm 1975, tại một số vùng có đất đai ven sông suối màu mỡ, nguồn nước tưới thuận lợi, người Cơ-ho tích cực khai hoang, mở rộng diện tích canh tác lúa nước, đáp ứng nhu cầu lương thực của gia đình. Theo kết quả điều tra, có 57 hộ trong mẫu điều tra (chiếm 20\%) có canh tác lúa nước. Canh tác lúa nước ngày nay không sử dụng cách thức trâu quần, cày bừa truyền thống mà hầu hết đã sử dụng máy móc hiện đại từ khâu làm đất đến khâu thu hoạch, với các giống lúa mới, ngắn ngày và cho năng suất cao hơn các giống lúa truyền thống. Bên cạnh đó, Nhà nước đã quan tâm đầu tư xây dựng, nâng cấp các công trình thủy lợi, góp phần chủ động nước tưới cho canh tác lúa nước của người Cơ-ho ở các địa phương.

Trong những năm gần đây, một số hộ người Cơ-ho tại các địa phương như Đà Lạt, Lạc Dương, Đức Trọng, Đơn Dương là những vùng sản xuất rau hoa thương phẩm lớn của tỉnh đã đầu tư vốn, học hỏi kỹ thuật sản xuất, chuyển đổi các diện tích lúa một vụ sang trồng các loại rau, hoa chất lượng cao phục vụ cho thị trường. Trong đó, có một số gia đình Cơ-ho đã dịch chuyển sang các mô hình nông nghiệp công nghệ cao (nhà kính, tưới phun sương, tưới nhỏ giọt, trồng trên giá thể, thủy canh, trồng rau sạch theo tiêu chuẩn VietGAP (Vietnamese Good Agricultural Practices). Thực hành sản xuất nông nghiệp tốt ở Việt Nam) đem lại thu nhập cao, như ở thị trấn Lang Biang, xã Lát (huyện Lạc Dương), xã N'thôl Hạ, Hiệp An, Hiệp Thạnh, Phú Hội (xã Đức Trọng),...

Cùng với sự phát triển của các loại hình trồng trọt định canh, hoạt động canh tác nương rẫy truyền thống của người Cơ-ho ngày càng thu hẹp và dần biến mất. Nguyên nhân là do diện tích rừng đã bị thu hẹp và chính sách cấm phá rừng làm nương rẫy của Nhà nước nên họ không còn những không gian rộng lớn phục vụ cho loại hình "du canh luân khoảnh" này.

Chăn nuôi vẫn tiếp tục được người Cơ-ho duy trì và chủ yếu để phục vụ cho nhu cầu gia đình (theo kết quả khảo sát, $52 \%$ gia đình có chăn nuôi gia súc và $39 \%$ có chăn 
nuôi gia cầm). Nhìn chung, quy mô chăn nuôi của người Cơ-ho mang tính chất nhỏ lẻ, manh mún trong phạm vi gia đình. Có một số gia đình nuôi trâu với số lượng lớn, chủ yếu được chăn thả nhưng vẫn còn một số nơi, trâu vẫn được nuôi thả rông trong rừng (xã Lát, huyện Lạc Dương).

Các nghề thủ công truyền thống dần mai một. Nghề rèn gần như biến mất. Nghề đan lát phổ biến một thời nay chỉ còn duy trì ở lớp người lớn tuổi. Nghề dệt chỉ còn ở một số hộ gia đình, nhưng đã chuyển sang sử dụng sợi màu mua sẵn từ chợ thay cho việc trồng bông, se sợi, nhuộm vải truyền thống. Một số mô hình làng nghề dệt cổ truyền được xây dựng nhưng hầu hết thất bại sau thời gian thí điểm hoặc còn tồn tại nhưng đối diện với nhiều khó khăn. Nguyên nhân chính của tình trạng trên đây là do sự phát triển mạnh mẽ của kinh tế thị trường, các loại vật dụng gia đình cũng như quần áo may sẵn có màu sắc và mẫu mã đa dạng, phù hợp với xã hội hiện đại, giá cả phải chăng đã tràn khắp các bon, đáp ứng tốt nhu cầu sử dụng và thị hiếu đã có nhiều thay đổi của người dân. Vì vậy, những loại sản phẩm đan lát, dệt truyền thống dù bền chắc nhưng tốn nhiều lao động, giá cao, sản phẩm đơn điệu gắn với nền kinh tế tự cung tự cấp trước kia nên dần mất khả năng cạnh tranh. Trừ một số sản phẩm đan lát (phổ biến nhất là gùi), các sản phẩm dệt (tắm đắp - ùi, túi sách, khăn, dây đeo tay) chủ yếu phục vụ cho nhu cầu quà lưu niệm của khách du lịch hoặc những nhu cầu mang tính tinh thần của người Cơ-ho (phục vụ cho nghi lễ cưới hỏi, tang ma) hơn là phục vụ cho những nhu cầu sử dụng trong đời thường.

Hiện nay, trên địa bàn cư trú của người Cơ-ho, rừng đã suy giảm nhiều về diện tích và các sản vật rừng. Các hoạt động kinh tế chiếm đoạt không thường xuyên và phổ biến như trước. Nhưng với tâm thức của “những người con của rừng”, người Cơ-ho vẫn cho rằng rừng đóng vai trò quan trọng trong đời sống. Theo kết quả điều tra, có 127 hộ (chiếm $50.2 \%$ ) cho rằng rừng có chức năng chống xói mòn đất, có 82 hộ $(32.4 \%)$ cho rằng rừng góp phần cung cấp thức ăn, có 71 hộ $(28.1 \%)$ cho rằng rừng cung cấp gỗ để làm nhà, 33 hộ $(13 \%)$ cho rằng rừng cung cấp cây thuốc chữa bệnh.

Thực hiện chính sách chi trả dịch vụ bảo vệ môi trường rừng, người Cơ-ho ở các xã trong khu vực rừng quốc gia, rừng đầu nguồn, rừng của các lâm trường... đã tích cực nhận khoán quản lý bảo vệ rừng. Hoạt động này đã đem lại một nguồn thu nhập đáng kể, 
góp phần cải thiện đời sống người dân. Theo kết quả điều tra, có 93 hộ (chiếm 31.5\%) tham gia nhận chăm sóc bảo vệ rừng. Trung bình với diện tích nhận giao khoán khoảng 20 - 30ha, đem lại thu nhập từ 9 - 10 triệu đồng/năm. Tuy vậy, con số này không đồng đều ở các địa phương, phụ thuộc vào diện tích rừng hiện còn tồn tại trên địa bàn.

Hiện nay, kinh tế thị trường đã xâm nhập mạnh vào đời sống kinh tế của người Cơ-ho. Quan hệ tiền tệ đã thay thế cho phương thức vật đổi vật truyền thống. Việc trao đổi, mua bán ở chợ diễn ra phổ biến ở các thị trấn, xã gần trung tâm. Với những làng ở xa trung tâm, việc mua bán chủ yếu diễn ra ở hệ thống các quán tạp hóa trong làng. Trong các bon người Cơ-ho, thường có một vài cơ sở thu mua nông sản khá lớn, đa phần là của người Kinh. Đây đồng thời cũng là nơi cung cấp các dịch vụ vật tư nông nghiệp (phân bón, máy móc) và tín dụng cho người dân.

Trong những năm gần đây, ở các khu vực gần trục giao thông, gần trung tâm, vùng đang diễn ra quá trình đô thị hóa mạnh mẽ (như thị trấn Lạc Dương, huyện Lạc Dương), nhiều hộ gia đình người Cơ-ho cũng đã tham gia vào các hoạt động kinh tế phi nông nghiệp: Mở cửa hàng bán cà phê - giải khát, ăn uống, tạp hóa, tiệm gội đầu, uốn tóc, tiệm sửa chữa xe máy, điện thoại di động, đại lý thu mua nông sản, cung cấp phân bón và vật tư nông nghiệp... nhưng nhìn chung có quy mô nhỏ lẻ, mang tính chất thời vụ, khả năng cạnh tranh thấp. Với hầu hết các gia đình này, các hoạt động kinh tế phi nông nghiệp vẫn là loại hình kinh tế phụ, sinh kế chính của gia đình vẫn dựa vào kinh tế nông nghiệp. Tuy vậy, sự xuất hiện các loại hình hoạt động kinh tế dịch vụ cũng đã thể hiện được khả năng thích nghi và hội nhập của người Cơ-ho ở những khu vực này với những chuyển đổi không gian và bối cảnh kinh tế - xã hội của quá trình đô thị hóa.

Trong khi đó, tại các địa phương vùng sâu, vùng xa, các hoạt động buôn bán, dịch vụ vẫn chủ yếu nằm trong tay người Kinh. Theo kết quả khảo sát, trong 300 người được hỏi, chỉ có 5 người Cơ-ho làm nghề buôn bán (chiếm tỷ lệ 1.7\%). Có thể nói, mặc dù đã có một thời gian dài tiếp xúc với phương thức trao đổi hàng hóa thông qua quá trình chuyên canh cây công nghiệp, đến nay người Cơ-ho tại nhiều địa phương vẫn còn khá xa lạ với loại hình công việc kinh doanh và cung cấp dịch vụ. Đặc tính tự cung, tự cấp vẫn còn in đậm trong tư duy, tâm lý của cộng đồng cư dân này. 
Theo kết quả điều tra, trong những năm gần đây, làm thuê là một hoạt động kinh tế quan trọng của người Cơ-ho, mang lại nguồn thu nhập đáng kể (176 hộ có thu nhập từ làm thuê, chiếm 61.8\%), chỉ xếp sau nguồn thu từ trồng trọt (263 hộ, chiếm 92.3\%). Hoạt động làm thuê phổ biến của người Cơ-ho là trồng cây, bón phân, làm cỏ, chăm sóc, thu hoạch nông sản cho người Kinh trong các rẫy chuyên canh cây công nghiệp, vườn và trang trại rau hoa thương phẩm ở trong vùng. Thời gian làm việc khoảng 8 tiếng/ngày, tiền công dao động khoảng 90000 đ - 150000đ/ngày tùy tính chất công việc và giới tính (thường công lao động nam cao hơn công lao động nữ). Việc làm này đem lại thu nhập đáng kể cho các gia đình người Cơ-ho, giúp họ có công ăn việc làm ổn định vào dịp nông nhàn và giúp giải quyết việc làm cho thanh niên thiếu đất sản xuất. Song, suy cho cùng, công việc làm thuê này cũng chỉ là sự dịch chuyển các hoạt động sản xuất nông nghiệp từ khu rẫy gia đình sang khu rẫy, vườn của người chủ khác. Tương tự các tộc người tại chỗ khác ở Tây Nguyên, với người Cơ-ho ở Lâm Đồng, nông nghiệp luôn là không gian sinh tồn chủ đạo của họ (Lê \& Phạm, 2013, tr. 207).

Thành phố Đà Lạt nói riêng, Lâm Đồng nói chung là thương hiệu du lịch nổi tiếng của cả nước, hấp dẫn du khách trong nước và quốc tế. Trong các tài nguyên du lịch của địa phương, bản sắc văn hóa truyền thống của các tộc người bản địa được xem là nguồn tài nguyên du lịch nhân văn quan trọng, với các sản phẩm du lịch thường được đề cập đến: Lễ hội truyền thống, âm nhạc cồng chiêng, văn hóa ẩm thực, các sản phẩm thủ công truyền thống... Tận dụng được thế mạnh đó, người Cơ-ho dưới chân núi Lang Biang, thị trấn Lạc Dương, huyện Lạc Dương đã có những hoạt động hướng đến dịch vụ du lịch với mô hình du lịch văn hóa cồng chiêng. Một số người có vốn và khả năng tổ chức đã đầu tư xây dựng sân khấu biễu diễn, sân bãi đậu ô tô, tập hợp đội đánh cồng chiêng, đội múa để tổ chức thành điểm biểu diễn cồng chiêng. Hiện nay, tại thị trấn này, trên phạm vi khoảng $2 \mathrm{~km}^{2}$, có 10 điểm du lịch cồng chiêng, sức chứa lên đến $200 \mathrm{khách/điểm.} \mathrm{Hoạt}$ động kinh tế này đã thu hút khoảng 400 người dân địa phương tham gia thường xuyên. Đa phần là những nghệ nhân cồng chiêng và thanh niên nam nữ hoạt động bán chuyên nghiệp (ban ngày tham gia lao động sản xuất, ban đêm tập luyện và biễn diễn phục vụ du lịch). Các cơ sở này thường liên hệ với các công ty du lịch tổ chức các tour đưa du khách tham gia liên hoan cồng chiêng hằng đêm. Các hoạt động gồm biểu diễn âm nhạc cồng 
chiêng, múa truyền thống kết hợp với các nhạc cụ và dân vũ hiện đại. Cùng với đó, du khách sẽ được thăm nhà dài trưng bày các sản phẩm văn hóa truyền thống của người Cơho, được giao lưu lửa trại, thưởng thức thịt nướng, rượu cần với người bản địa. Hoạt động du lịch này cũng tạo động lực thúc đẩy một số gia đình người Cơ-ho trong vùng đưa những sản phẩm truyền thống của mình như rượu cần, thổ cẩm... thành hàng hóa bán cho khách du lịch.

Mặc dù hiện nay vẫn còn có nhiều ý kiến trái chiều về chất lượng, cách thức tổ chức và ảnh hưởng của hoạt động dịch vụ du lịch này nhưng rõ ràng, đây là một loại hình kinh tế dịch vụ thể hiện sự đổi mới trong tư duy của người Cơ-ho nơi đây. Họ biết tận dụng và phát huy lợi thế văn hóa của mình để cải thiện sinh kế của mình. Bên cạnh đó, hoạt động này góp phần làm phong phú sản phẩm du lịch của địa phương và góp phần bảo lưu giá trị văn hóa truyền thống của cộng đồng (mặc dù các sinh hoạt văn hóa đó không phải lúc nào cũng theo đúng cách thức truyền thống). Ngoài ra, các đội cồng chiêng, đội múa của người Cơ-ho ở Lạc Dương còn tham gia phục vụ tại các địa điểm du lịch của Đà Lạt như Đồi Mộng Mơ, Thung lũng Tình yêu, Vườn hoa Thành phố, Làng Cù Lần... hoặc phục vụ âm nhạc cho đám cưới của người Cơ-ho và cả người Kinh ở trong vùng. Tuy vậy, các hoạt động này chỉ mới tập trung ở thị trấn Lang Biang - địa phương tiếp giáp thành phố Đà Lạt, có thế mạnh về du lịch và đang trong quá trình đô thị hóa mạnh mẽ, chứ chưa phổ biến ở các cộng đồng người Cơ-ho ở các nơi khác của tỉnh Lâm Đồng.

\section{MộT SỐ VẨN ĐỀ ĐặT RA CHO PHÁT TRIỂN BỀn VŨ̉NG KINH TẾ NGƯỜI CÖ-HO}

Bên cạnh mảng màu tích cực nổi trội và chiếm ưu thế, sự biến đổi trong kinh tế của người Cơ-ho ở Lâm Đồng hiện cũng đang đặt ra một số thách thức cần giải quyết để đảm bảo sự phát triển bền vững. Trong đó, theo chúng tôi, nổi lên những vấn đề sau:

- Thiếu đất sản xuất: Trong những năm qua, tỉnh Lâm Đồng đã ban hành nhiều chính sách nhằm giải quyết vấn đề đất canh tác cho người dân tộc thiểu số tại chỗ. Tuy nhiên, một số gia đình người Cơ-ho vẫn đang trong tình trạng thiếu đất sản xuất. Theo kết quả khảo sát, có 131 hộ (44.1\%) cho rằng gia đình 
mình đang thiếu đất sản xuất. Có nhiều nguyên nhân dẫn đến tình trạng này: Đất nghèo dinh dưỡng, năng suất thấp nên cần nhiều diện tích để sản xuất; những hộ nghèo, khó khăn do ốm đau, bệnh tật, con cái học hành, chi phí cho đám cưới theo tục lệ truyền thống, trả tiền vay lãi... thường bán đất để giải quyết những khó khăn trước mắt; Việc mua bán, sang nhượng đất đai trái phép, kể cả đất khai thác trái phép từ đất rừng bằng kênh phi chính thức, chủ yếu cho người Kinh (bằng giấy tay, không có sự quản lý và kiểm soát của của chính quyền) vẫn âm thầm diễn ra; Tỷ lệ tách hộ ngày càng nhanh, các hộ gia đình khi có con gái trưởng thành đi lấy chồng thường phải chia đất cho con, với các gia đình đông con thì phần đất chia ngày càng ít đi (Bùi, 2016, tr. 119). Thiếu đất sản xuất đã làm cho nhiều gia đình người Cơ-ho gặp khó khăn trong sinh kế. Từ đó, dẫn đến hiện tượng tranh chấp đất đai, khai phá rừng trái phép để làm rẫy trồng cà phê. Tại một số nơi như thôn 4 , xã Đạ Long (huyện Đam Rông), xã Mê Linh (huyện Lâm Hà) có hiện tượng người Cơ-ho quay trở lại làng cũ trong khu vực rừng quốc gia để sản xuất, tạo nên những điểm nóng phức tạp kéo dài trong nhiều năm.

- Nền sản xuất độc canh cà phê cần nhiều vốn đầu tu và có nhiều rủi ro: Không thể phủ nhận rằng, trong ba thập niên qua, cây cà phê đã góp phần không nhỏ vào việc nâng cao chất lượng cuộc sống người Co Ho ở tỉnh Lâm Đồng. Như đã đề cập ở trên, cũng như ở nhiều địa phương khác, trong cơn sốt giá cà phê, thu hoạch từ cà phê có giá trị cao nên nhiều người Cơ-ho đã tích cực chuyển đổi cơ cấu cây trồng, từ đa canh truyền thống sang độc canh cà phê theo hướng đầu tư thâm canh, sản phẩm làm ra $100 \%$ phục vụ cho thị trường. Điều người dân không tính đến là sự bấp bênh của thị trường và sự mất ổn định của các điều kiện đầu vào của sản xuất (cà phê rớt giá, hạn hán và các thiên tai khác, khi chất lượng cà phê thấp, mở rộng diện tích thiếu quy hoạch...). Vì vậy, khi cà phê không tiêu thụ được, rớt giá hoặc vụ mùa thất bất thì khó có thể tìm kiếm nguồn sinh kế khác để tồn tại, điều mà trong truyền thống họ không phải đối diện vì có sự trợ giúp đắc lực từ rừng và rẫy đa canh với các loại cây lương thực truyền thống (Mai, 2012, tr. 43). Thực tế tại nhiều vùng 
Cơ-ho ở Lâm Đồng, do đất đai bạc màu, giá cà phê chững lại ở mức thấp, cây cà phê già cỗi cho năng suất thấp, hạn hán... nhiều hộ dân gặp khó khăn, phải dựa vào sự hỗ trợ, cứu đói của Nhà nước.

- Thiếu vốn đầu tu sản xuất và nguy cơ tín dụng đen: Theo kết quả điều tra, thiếu vốn đầu tư là khó khăn lớn nhất, phổ biến nhất mà các hộ gia đình Cơho gặp phải trong quá trình sản xuất (có 254 hộ trong mẫu khảo sát, chiếm $82.5 \%)$. Điều này có thể lý giải là do việc thâm cây cà phê đòi hỏi vốn đầu tư lớn cho việc bón phân, dầu chạy máy bơm nước tưới, hơn nữa đầu tư, chăm sóc một năm mới cho thu hoạch một lần vào những tháng cuối năm. Vì vậy, chỉ ở những xã có diện tích đất bazan rộng lớn, đời sống và thu nhập khá giả, người Cơ-ho có đủ nguồn lực tài chính để đầu tư mạnh cho sản xuất, tái canh cà phê. Ngược lại, tại những xã ở xa trung tâm, điều kiện kinh tế khó khăn, đất đai bạc màu (chiếm tỷ lệ khá lớn), đa phần diện tích cà phê của người Cơho thuộc giống cũ, đã già cỗi nên cho năng suất thấp (khoảng dưới 2 tấn/ha). Thu nhập không ổn định, trong khi giá cả phân bón, đầu vào sản xuất lại cao nên người dân không đủ khả năng đầu tư thỏa đáng cho sản xuất. Vì vậy, ở những vùng này, tái canh ít được họ quan tâm vì cho rằng sẽ làm gián đoạn nguồn thu và phải đầu tư lại từ đầu. Bên cạnh đó, nền kinh tế đơn canh gắn với thị trường đã hình thành cho người Cơ-ho hành vi và thói quen tiêu dùng mới. Từ tiền bán cà phê hoặc làm công, người dân hầu hết phải mua mọi thứ cần thiết, phục vụ cho nhu cầu cuộc sống. Họ cũng có cơ hội tiếp cận và hưởng thụ tất cả các mặt hàng trước đây được coi là xa xỉ. Ngoài ra, tâm lý làm đến đâu, tiêu đến đấy vẫn còn phổ biến trong đông đảo người dân. Không ít gia đình đã dùng những khoản tiền khá lớn so với thu nhập của gia đình để sắm sửa những vật dụng, tiện nghi đắt tiền không phải để phục vụ sản xuất, không sinh lời mà chỉ tăng thêm giá trị cuộc sống. Thiếu vốn đầu tư sản xuất và các nhu cầu khác, người dân phải vay nợ, chủ yếu là từ ngân hàng hoặc các dịch vụ cho vay tư nhân lãi suất cao. Theo kết quả khảo sát của đề tài, có 235 hộ (chiếm 78.8\%) cho biết gia đình hiện đang vay nợ. Trong đó, cao nhất là từ Ngân hàng Chính sách Xã hội (177 hộ, chiếm 73.1\%), dịch vụ cho vay 
tư nhân hoặc vay thông qua mua nợ vật tư, hàng hóa tiêu dùng (88 hộ, chiếm 34.8\%), Ngân hàng thương mại (25 hộ, chiếm 10.3\%). Trong công trình nghiên cứu về tín dụng vùng dân tộc thiểu số, Hoàng và ctg. (2017) đã đưa ra số liệu khảo sát cụ thể về tình trạng nợ đáng lo ngại của người Cơ-ho ở Buôn Ban, xã Phú Sơn, huyện Lâm Hà, tỉnh Lâm Đồng: Trung bình mỗi hộ Cơ-ho ở đây nợ 42.8 triệu/năm, trong đó có 19 triệu là nợ xấu (tức khoản vay không có khả năng trả hoặc trả không đúng hạn). Đáng chú ý là có tới 53.4\% là vay từ hộ đại lý kinh doanh vật tư nông nghiệp và nguồn vay này chiếm 73.3\% nợ xấu của các hộ gia đình (Hoàng \& ctg., 2017, tr. 46). Rõ ràng, thiếu vốn đầu tư sản xuất và tín dụng đen là một thách thức lớn đối với sự phát triển bền vững của người Cơ-ho ở nhiều địa phương.

- Trinh độ kỹ thuật sản xuất thấp, thiếu việc làm, đặc biệt là việc làm cho thanh niên: Trong tác phẩm Hướng tới phát triển bền vững vùng Tây Nguyên, các tác giả nhận định rằng hiện nay, đội ngũ lao động người dân tộc thiểu số tại chỗ Tây Nguyên rất dồi dào với cơ cấu dân số trẻ, nhưng nhìn chung chất lượng nguồn nhân lực thấp (Lê \& Phạm, 2013, tr. 205-207). Ở người Cơ-ho, tình hình cũng không nằm ngoài bức tranh chung đó. Hiện nay, tỷ lệ học sinh người Cơ-ho học lên bậc THPT, Trung cấp, Cao đẳng, Đại học chiếm tỷ lệ thấp. Số học sinh bỏ học giữa chừng cao, khả năng tiếp cận môi trường giáo dục bậc cao, trong đó có đào tạo nghề hạn chế, mặc dù đã có nhiều chương trình, dự án đào tạo nghề của Nhà nước được triển khai. Chính vì vậy, lao động người Cơ-ho chủ yếu đóng khung trong các hoạt động canh tác nông nghiệp. Nếu có hoạt động làm thuê thì cũng chủ yếu là các hoạt động chân tay thuần túy trong nông nghiệp: Trồng cây, bón phân, làm cỏ và thu hoạch nông sản. Đời sống và sinh kế gắn chặt với nông nghiệp và nông thôn, không có nhiều cơ hội và năng lực để chuyển đổi sang các lĩnh vực lao động phi nông. Mặc dù đã gắn bó với kinh tế hàng hóa trong nhiều thập kỷ nhưng người Cơ-ho tại nhiều địa phương vẫn còn mang đậm tư duy tự cấp tự túc truyền thống, ít muốn rời xa cộng đồng, ruộng vườn và các hoạt động sản xuất nông nghiệp. Tình trạng này đã đặt ra nhiều hệ lụy kinh tế - xã hội trước 
mắt và lâu dài. Toàn bộ gánh nặng thu nhập của các hộ gia đình sẽ dồn lên quỹ đất nông nghiệp đang ngày càng suy giảm về diện tích và độ màu mỡ. Mặt khác, do không có khả năng chuyển đổi nghề nghiệp, nguồn lao động dư thừa trong sản xuất nông nghiệp có nguy cơ bị rơi vào các tệ nạn xã hội mới như nghiện ma túy, trộm cắp... là những điều xa lạ với xã hội Cơ-ho trong truyền thống.

- Sản xuất nông nghiệp chura gắn với với bảo vệ và phát triển tài nguyên rùng: Mặc dù tại nhiều địa phương, chính sách giao khoán bảo vệ rừng được thực hiện hiệu quả, vừa tăng thu nhập cho người dân, vừa bảo vệ được nguồn tài nguyên rừng. Tuy nhiên, ở nhiều nơi, hiện tượng người dân khai thác các nguồn tài nguyên rừng vẫn diễn ra phổ biến, với các hoạt động như khai thác gỗ, đốt than, đặc biệt là lấn chiếm và phá rừng để lấy đất sản xuất... Tại nhiều vùng cư trú của người Cơ-ho, màu xanh của các dãy núi, cánh rừng dần nhường chỗ cho những rẫy cà phê được trồng lên đến tận đỉnh. Nguyên nhân của tình trạng này là do thiếu đất sản xuất, đời sống khó khăn, thiếu việc làm ổn định, sự buông lỏng quản lý của chính quyền địa phương, sự mất hiệu lực và biến mất của các tri thức, luật tục truyền thống về sử dụng và bảo vệ nguồn lợi rừng... Cả trước mắt và lâu dài, sự suy giảm của nguồn tài nguyên rừng rõ ràng ảnh hưởng lớn đến đời sống và sản xuất của người dân cũng như môi trường sinh thái tự nhiên.

- Biến đổi khí hậu và các sụ cố môi truờng khác: Trong những năm qua, tuy chưa có những nghiên cứu cụ thể nhưng những tác động tiêu cực của biến đổi khí hậu đến đời sống kinh tế của người Cơ-ho ở Lâm Đồng là điều dễ nhận thấy. Theo kết quả khảo sát của chúng tôi, có 157 người trả lời cho rằng thiên tai là một trong những khó khăn mà họ gặp phải trong quá trình sản xuất (chiếm $52.9 \%$, xếp thứ hai sau khó khăn vì thiếu vốn). Là những cư dân sống chủ yếu dựa vào trồng trọt (chủ yếu là cây công nghiệp), sống ở nhiều vùng có cơ sở hạ tầng, đường xá đi lại, hệ thống thủy lợi hạn chế, lại có đời sống kinh tế thấp hơn mặt bằng chung nên người Cơ-ho càng ít có điều kiện để tiếp cận các nguồn lực (cả tự nhiên, xã hội và tài chính) để đối phó với 
biến đổi khí hậu. Vì vậy, họ là đối tượng chịu tác động lớn hơn của những tai biến của tự nhiên so với những cư dân khác. Năm 2016, trận hạn hán kỷ lục đã làm cho 40000ha đất sản xuất và 6690 hộ dân ở Lâm Đồng bị thiếu nước sản xuất và sinh hoạt. Nhiều rẫy cà phê bị giảm năng suất, không cho thu hoạch thậm chí chết khô. Chính quyền đã phải xuất gạo, hỗ trợ cứu đói giáp hạt cho người DTTS trên địa bàn tỉnh, trong đó có người Cơ-ho ở Đà Lạt, Đơn Dương, Lâm Hà, Đam Rông,... Biến đổi khí hậu cùng với diện tích rừng bị thu hẹp, đất đai bạc màu, hoang hóa, mực nước ngầm xuống thấp,... rõ ràng đang đặt ra người Cơ ho những thách thức không nhỏ trong sinh hoạt và sản xuất.

\section{KẾT LUẬN}

Từ năm 1986 đến nay, các chính sách Đổi mới của Đảng và Nhà nước cũng như quá trình công nghiệp hóa - hiện đại hóa, đô thị hóa và thị trường hóa đã làm thay đổi một cách căn bản hoạt động kinh tế của người Cơ-ho ở Lâm Đồng theo hướng chuyển nhanh từ sản xuất tự nhiên, tự cung, tự cấp lương thực sang sản xuất nông nghiệp hàng hóa, phục vụ thị trường xuất khẩu với cà phê là cây trồng chủ lực. Sự thay đổi đó đã kéo theo sự chuyển biến mạnh mẽ về chu trình, kỹ thuật canh tác, mối quan hệ giữa sản xuất với tiêu dùng và biến đổi các hoạt động sinh kế khác. Các loại hình kinh tế truyền thống như canh tác nương rẫy, kinh tế chiếm đoạt tự nhiên, nghề thủ công ngày càng thu hẹp, suy giảm vai trò. Xuất hiện một số hoạt động kinh tế mới như làm thuê trong nông nghiệp, buôn bán nhỏ, dịch vụ,... Những biến đổi trong hoạt động kinh tế đã tạo động lực làm thay đổi tích cực nhiều mặt đời sống của người dân: Tỷ lệ nghèo đói giảm mạnh, đời sống vật chất, tinh thần ngày càng được nâng cao, bộ mặt nông thôn có nhiều khởi sắc,...

Tuy vậy, quá trình biến đổi kinh tế của người Cơ-ho ở Lâm Đồng hiện cũng bộ lộ nhiều điểm yếu và thách thức: Tình trạng thiếu đất sản xuất, những rủi ro đến từ nền sản xuất độc canh cây công nghiệp gắn với thị trường nhiều biến động về giá cả, thiếu vốn sản xuất và nguy cơ rơi vào vòng xoáy của tín dụng đen, trình độ nguồn nhân lực hạn chế, thiếu việc làm và thu nhập không ổn định, sản xuất nông nghiệp chưa gắn với bảo vệ và phát triển tài nguyên rừng, tác động ngày càng lớn của biến đổi khí hậu và các sự cố môi trường. Vì vậy, các cấp chính quyền phải khách quan nhìn nhận những khó khăn, thách 
thức này để tìm những giải pháp toàn diện, hiệu quả, đảm bảo tính bền vững trong sự phát triển kinh tế của người Cơ-ho ở Lâm Đồng.

\section{TÀI LIỆU THAM KHẢO}

Bùi, M. Đ. \& Vũ, T. H. (2001). Nguời Cơho ở Việt Nam. Hà Nội, Việt Nam: NXB. Văn hóa Dân tộc.

Bùi, M. Đ. (2016). Một số biến đổi kinh tế - xã hội của người Cơ-ho ở huyện Di Linh, tỉnh Lâm Đồng trong thời kỳ Đổi mới. Tạp chí Dân tộc học, 1 \&2(194), 47-54.

Bùi, Q. D. (2016). Vấn đề nông nghiệp, nông dân và nông thôn trong phát triển bền vũng Tây Nguyên [Đề tài nghiên cứu khoa học trọng điểm cấp quốc gia thuộc Chương trình Tây Nguyên 3]. Hà Nội, Việt Nam: Viện Hàn lâm Khoa học Xã hội Việt Nam.

Cao, T. T. (1996). Văn hóa truyền thống $M a-C o ̛$-ho [Đề tài nghiên cứu khoa học cấp tỉnh]. Lâm Đồng, Việt Nam: Trường Đại học Đà Lạt.

Hoàng, C., Ngô, T. P. L., Hoàng, A. D., Vũ, T. L., \& Nguyễn, V. G. (2017). Chuyển đổi sinh kế và vấn đề tín dụng ở một số tộc người thiểu số tại Tây Nguyên và Tây Bắc. Hà Nội, Việt Nam: Viện ISEE.

Lê, Đ. B. \& Mai, M. N. (2011). Những nghi lễ trong chu kỳ canh tác nương rẫy của người Chil tại xã Đạ Long, huyện Đam Rông, tỉnh Lâm Đồng. Tạp chí Khoa học Đại học Đà Lạt, (1), 175-184.

Lê, H. L. (2016). Vai trò văn hóa và lối sống trong phát triển bền vũng Tây Nguyên [Đề tài nghiên cứu khoa học trọng điểm cấp quốc gia thuộc Chương trình Tây Nguyên 3]. Hà Nội, Việt Nam: Viện Hàn lâm Khoa học Xã hội Việt Nam.

Lê, M. C. (2017). Biến đổi trong tổ chức xã hội của cộng đồng nguời Cơ-ho trong tiến trình đô thị hóa ở thị trấn Lac Duơng, huyện Lac Dương, tỉnh Lâm Đồng. (Luận án tiến sĩ), Viện Hàn lâm Khoa học Xã hội Việt Nam, Việt Nam.

Lê, V. K. \& Phạm, Q. T. (2014). Huớng tới phát triển bền vũng Tây Nguyên. Hà Nội, Việt Nam: NXB. Tri thức.

Mai, T. S. (2012). Chính sách đất đai và văn hóa tộc người: Nghiên cứu truờng hợp tại tỉnh Đăk Lăk. Hà Nội, Việt Nam: NXB. Thế giới.

Nguyên, N. (2008). Phát triển bền vững ở Tây Nguyên. Trong Nhiều tác giả, Nông dân, nông thôn, nông nghiệp (tr. 137-184). Hà Nội, Việt Nam: NXB. Tri thức.

Phan, N. C. (2005). Người Ko ho ở Lâm Đồng - nghiên cưu nhân học về dân tộc và văn hóa. TP. Hồ Chí Minh, Việt Nam: NXB. Trẻ.

Thành, P. \& Niê K'dăm, H., \& Ikemoto, Y. (2007). Cà phê ở Tây Nguyên - tiếp cận lịch sư, nhân học và kinh tế. TP. Hồ Chí Minh, Việt Nam: NXB. Đại học Quốc gia TP. Hồ Chí Minh.

Vũ, Đ. M. (2016). Biến đổi kinh tế - xã hội của các dân tộc thuộc nhóm ngôn ngữ Môn Khmer từ Đổi mới đến nay và những vấn đề nghiên cứu đặt ra. Tạp chí Dân tộc hoc, $1 \& 2(194), 63-74$. 


\title{
TRANSFORMATIONS IN ECONOMIC ACTIVITIES OF CO-HO PEOPLE IN LAMDONG PROVINCE SINCE RENOVATION TO PRESENT
}

\author{
Le Minh Chien ${ }^{a^{*}}$, Mai Minh Nhat ${ }^{\mathrm{b}}$ \\ ${ }^{a}$ The Faculty of Social Work, Dalat University, Lamdong, Vietnam \\ ${ }^{b}$ The Faculty of History, Dalat University, Lamdong, Vietnam \\ *Corresponding author: Email: chienlm@dlu.edu.vn \\ Article history \\ Received: October $26^{\text {th }}, 2017$ \\ Received in revised form: November $28^{\text {th }}, 2017$ | Accepted: November $29^{\text {th }}, 2017$
}

\begin{abstract}
This paper presents the transformation in economic activities of Co-ho people in Lamdong province under the influence of the Renovation policy by the Vietnamese Party and State, along with the process of industrialization, modernization, global integration and the local social-economic fluctuations in Lamdong province since 1986. It also analyses the challenges that the people of Co-ho community face concerning their economic development today.
\end{abstract}

Keywords: Co-ho people; Economic activity; Economic transformation; Lamdong province. 